\title{
¿En las puertas del horno se quema el pan de la demarcación territorial?
}

Si bien la aprobación de la ley de demarcación (Ley 445) se dio durante el gobierno liberal en 2002, ésta no hubiera sido posible sin la lucha que por esta causa venían llevando a cabo los pueblos indígenas desde la incorporación del Caribe nicaragüense al territorio nacional en 1894; tampoco hubiera cuajado sin la alianza que por la aprobación de esta Ley se llevó a cabo entre las organizaciones costeñas y el Frente Sandinista, asociación que aseguró no solo los votos para la aprobación de dicha Ley sino también la aceleración del proceso de titulación de los territorios durante la posterior administración sandinista del País.

Sin embargo, los elementos que en la actualidad están frenando la mayor y más antigua aspiración de la comunidad costeña son, por un lado, la inmigración de colonos empobrecidos hacia territorios indígenas, promovida por clientelismo político y agravada por un entramado de tráfico ilegal de tierras que involucra a funcionarios y particulares mestizos y también a dirigentes indígenas igualmente corruptos. Y por otro lado debido, a estas alturas del conflicto, a la falta de voluntad política del gobierno de Nicaragua para solucionar el conflicto. Esto lo evidencia la aparente incapacidad del aparato estatal, especialmente de parte de las fuerzas públicas cuya efectividad contra este tipo de delitos que involucran a agresores armados es sin duda eficiente, pero que, en el caso de los indígenas, sospechosamente no han podido dar respuesta definitiva.

¿Cuáles son las razones para que un gobierno que otrora enarboló, a nivel continental, la bandera de la demarcación y titulación para las comunidades indígenas y las afrodescendientes, ahora parece simular debilidad e incompetencia en completar un proceso vital para detener el avance de la frontera agrícola y favorecer estratégicamente el desarrollo y la conservación ambiental no solo del Caribe sino también del país? ¿Acaso, luego de contemplar el nuevo mapa de Nicaragua que delimita en más del treinta por ciento la propiedad territorial que incluye los mejores y más abundantes recursos naturales del país, ha renunciado -en virtud de qué otro interés o estrategia- a completar satisfactoriamente el proceso de reconocimiento de la propiedad territorial?

Sería lamentable si el FSLN hubiera cambiado de opinión, puesto que esto derivaría a la postre, y en el peor de los casos, en la invalidación de una propuesta estratégica de nación, en el debilitamiento de la propiedad territorial y de sus autoridades, en la degradación ambiental de las zonas protegidas y bosques del país, en la reducción del capital moral del FSLN en cuanto a restitución de derechos y en un descontento que en la década de los ochenta trajo la inestabilidad política en las actuales regiones autónomas.

No obstante, una promesa hecha por el Presidente de la República en una entrega de títulos a comunidades indígenas el veintinueve de octubre pasado parece desvirtuar, felizmente, esta sospecha y vislumbrar un cambio en la disposición política del Gobierno en torno a la desesperada situación en los territorios indígenas asediados. En esa ocasión, el comandante Ortega anunció la conformación de una comisión para resolver el saneamiento efectivo de los territorios indígenas mediante la reubicación de los colonos. Un anuncio que viniendo del comandante Daniel Ortega alegró a la comunidad costeña y a todo aquel simpatizante de la causa indígena. Porque si bien es cierto que el actual conflicto involucra dos sectores de la población tradicionalmente desposeída y explotada, sin embargo existe una máxima jurídica que dice Prior in tempore, potior in iure: primero en tiempo, primero en derecho. Y son los indígenas quienes viven allí desde antes de la venida de Colón y quienes han sufrido por más tiempo la violación a sus territorios y el enriquecimiento de otros a costa de sus recursos naturales.

Aún no se ha concretizado la conformación de la Comisión. Sin embargo, a partir de su anuncio, los acosos y ataques a las comunidades indígenas han decrecido evidenciando -es nuestra esperanza- un cambio en la voluntad política del Presidente y la consecuente resolución del más antiguo de los conflictos de propiedad en Nicaragua.

\section{Alvaro Rivas Gómez}

Editor Wani 